\section{Probe to catch rhino poacher}

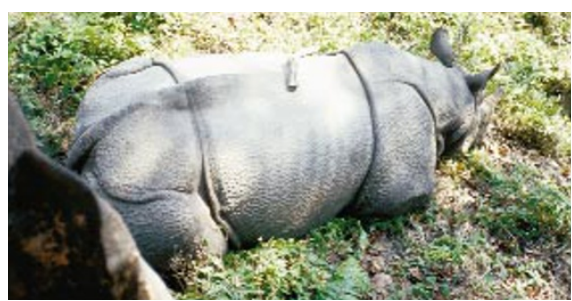

Rhinoceros horn-the natural, but politically incorrect version of viagra - can now be protected from poachers using DNA technology. Scientists at the National Institute of Immunology in India (NII; New Delhi) have just completed six months of tests on a DNA detection device that has not only been shown to detect rhino horn but also to tell whether the specimen comes from India or elsewhere. "It will be a valuable weapon in the hands of conservationists wanting to track down the source of rhino horn in the illegal market," says Sher Ali, head of NII's molecular genetics laboratory. Ali and his colleagues have discovered a repetitive 906 base pair DNA sequence that is unique to India's one-horned rhinoceros (Rhinoceros unicornis). The sequence is not present in the closely related African double-horned black rhinoceros (Diceros bicornis) or any other species of rhino. "This distinguishing feature will help identify if a particular horn came from India or Africa," says Ali. The great Indian one-horned rhino is an endangered species-currently numbering about 2000 - and is confined to three or four protected forests in Assam and West Bengal in eastern India.

\section{AHP and Monsanto part}

On October 13, Monsanto (St Louis, MO) and American Home Products (AHP; Madison, NJ) cancelled their $\$ 33.6$ billion merger, which was originally announced in June (Nat. Biotechnol. 16:612). AHP CEO John Stafford and Monsanto CEO Robert Shapiro reportedly could not see eye to eye on how to run the combined company. Monsanto share price, which had been falling amid rumors the talks were in trouble, dropped over $24 \%$ on the day of the announcement. The split means Monsanto will not receive help from AHP in paying the $\$ 5.6$ billion bill for its recent purchases of DeKalb Genetics, Delta \& Pineland (Nat. Biotechnol. 16:497), and Cargill Seeds (Nat. Biotechnol. 16:703).

Business and Regulatory Briefs written by Vicki Brower, Stephen Cass, Emma Dorey, KS Jayaraman, Riku Lähteenmäki, Adam Michael, Ellen Peerenboom, and Asako Saegusa.

\section{Finns fear and favor biotech}

Seventy-one percent of Finns believe biotechnology will improve standards of living within 20 years, according to a survey of the Finnish public's opinions on science. Commissioned by Finnish Bioindustries (Helsinki, Finland), an association representing pharmaceutical and other companies, the survey asked the public whether biotechnology and other areas of science are useful or risky. When presented with the undefined term "genetechnology", $58 \%$ of Finns considered it useful for pharmaceutical and vaccine development, particularly in gene testing to identify inherited diseases, but almost a third thought it would worsen quality of life over the next 20 years. Seen even less favorably was agricultural biotechnology: Around half the population sees genetically modified foodstuffs as risky, and 93\% would like genetically modified food products to carry labels identifying the technology used during production.

\begin{tabular}{|lcc|}
\hline $\begin{array}{l}\text { Finnish consumer opinions of } \\
\text { biotechnology applications. }\end{array}$ \\
\hline Application & Useful (\%) & Risky (\%) \\
\hline $\begin{array}{l}\text { Gene testing } \\
\text { (inherited diseases) }\end{array}$ & 71 & 11 \\
Medicines and vaccines & 58 & 25 \\
Gene modified plants & 42 & 47 \\
Foodstuffs & 32 & 53 \\
\hline
\end{tabular}

\section{Germany's plant genomics}

Nine days before Germany's government election, Jürgen Rüttgers, then-Minister for Education, Science, and Technology, earmarked DM5 million to fund the first year of a new plant genome project, due to start in September 1999. GABI (genome analysis of the plant biological system) aims to elucidate the Arabidopsis plant genome in the same way HUGO studied the human genome. Through a competition, companies and scientific institutes wishing to participate must apply for grants by January 4, 1999. GABI funds will go to the best proposals in structural genomics, functional genomics, applied genomics, and bioinformatics, but will also establish an infrastructure of patenting and licensing agencies to help protect intellectual property rights. Rüttgers planned GABI to run for eight years, and some industry representatives have speculated that GABI would receive as much as DM150 million funding. However, the new coalition government has a strong Green Party contingent, which may decide to change this-which is probably why Rüttgers initiated the scheme just before the general election of a new government took place over.

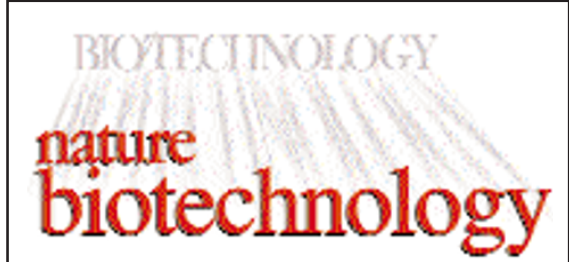

15 years ago-November 1983

- Tariffs and surpluses hinder development. Europe's food industry is apathetic and confused over where to go with biotechnology, and the European Economic Community and Europe's farmers are to blame, according to Trevor Palmer, technical director of Tunnel Refineries. Lakes of wine, mountains of butter, and a glut of pigs and chickens discourage companies from investing money in biotechnology to make food more efficiently, he told attendees at the First National Conference on Biotechnology in the Food \& Drink Industries, held in Brighton, UK.

- Increasing demand for biotechnology analysts. Securities firms are beefing up their research efforts in biotechnology and related fields. Growing investor interest and the slew of biotechnology public offerings has increased demand for qualified analysts. According to one researcher, an analyst can cover only about 20 companies thoroughly, and follow perhaps 20 more. The list of publicly held biotechnology specialty firms now numbers well over 20, so many securities houses may soon need a full-time biotechnology researcher. Such analysts require some scientific background in order to evaluate these highly technical companies, and Wall Street firms are actively recruiting from industry, academia, and other brokerage houses, as well as retraining inhouse personnel.

- New EPA regulations. The USEnvironmental Protection Agency has made a bold move in announcing that it intends to regulate the release of genetically modified organisms into the environment. Despite the cost (approx. \$10,000 to file) and the delay (at least 90 days) involved with submitting premanufacturing notices to the EPA, biotechnology product manufacturers will benefit from the regulations. They should welcome the EPA's recent move, a strictly legal interpretation of the influence it already exercises under the Toxic Substances Control Act and the Federal Insecticide, Fungicide, and Rodenticide Act. 